ISSN 0258-7122

Bangladesh J. Agril. Res. 38(1): 29-39, March 2013

\title{
EFFECT OF SOWING DATES ON YEAR ROUND PRODUCTION OF FOLIAGE OF CORIANDER (Coriandrum sativum L.)
}

\author{
M. MONIRUZZAMAN ${ }^{1}$, M. M. RAHMAN ${ }^{2}$, M. M. HOSSAIN ${ }^{3}$ \\ A. J. M. SIRAJUL KARIM ${ }^{4}$ AND Q. A. KHALIQ ${ }^{5}$
}

\begin{abstract}
Four genotypes of coriander (CS001, CS002, CS003, and CS004) were planted at twenty different dates starting from 01 March 2008 at 15 days interval to 15 February 2009 at the research farm of the Department of Horticulture, Bangabandhu Sheikh Mujibur Rahman Agricultural University (BSMRAU), Gazipur to assess the genotypes for year round production of foliage of coriander. It revealed that the number of plants $/ \mathrm{m}^{2}$ and foliage yield/ha decreased with the increase of temperature. The 01 January 2009 sowing gave the maximum foliage yield (6.38 t/ha) followed by 01 December 2008 sowing (6.05 t/ha). The genotype CS003 was the best yielder followed by CS001 and CS002. Performances of genotypes were the poorest during hot periods i.e. 01 April 2008 to 01 October 2008. The genotypes CS001, CS002 and CS003 performed better with regard to foliage production from 01 September 2008 to 15 February 2009 and in 15 March 2008, while the genotype CS008 gave better result from 15 October 2008 to 01 February 2009.
\end{abstract}

Keywords: Sowing dates, year round, coriander, Coriandrum sativum L., foliage yield.

\section{Introduction}

Coriander (Coriandrum sativum L.), an important spice crop is known as 'Dhania' in Bangla. It is a tasty herb grown for its pleasant aromatic leaves in all parts of Bangladesh. The entire plant of young coriander is used as appetizer in preparing fresh chutneys and sauces, leaves are used to flavour food, curries, soups, fish sauce, cream sauce for chicken, tomato soup, pickling sausages, bakery preparations, liqueurs, gins and meat (Janardhonan and Thoppil, 2004). Coriander is native to Southern Europe and the Mediterranean region. The genotypes available in the country grow well in rabi season due to congenial temperature for foliage production. But at present, there is no suitable genotype/variety for year round production of coriander leaves. There is increased interest in year round foliage production among growers as well as consumers. The plant is to be harvested for foliage before bolting otherwise leaf

\footnotetext{
${ }^{1}$ Senior Scientific Officer, HRC, Bangladesh Agricultural Research Institute (BARI), ${ }^{2}$ Professor, Dept. of Horticulture, Bangabandhu Sheikh Mujibur Rahman Agricultural University (BSMRAU), Salna, Gazipur-1706, ${ }^{3}$ Professor, Dept. of Horticulture, BSMRAU, Salna, Gazipur-1706, ${ }^{4}$ Professor, Dept. of Soil Science, BSMRAU, Salna, Gazipur-1706, ${ }^{5}$ Professor, Dept. of Agronomy, BSMRAU, Salna, Gazipur-1706, Bangladesh.
} 
becomes little bitter in taste. The optimum temperature for germination and early growth of coriander is $20-25^{\circ} \mathrm{C}$ (Sharma and Sharma, 2004). Hot weather causes cilantro (coriander grown for leaves) to bolt to seed very quickly and development of foliage nearly ceases and temperature between $10^{\circ}$ to $30^{\circ} \mathrm{C}$ provides optimum growing conditions for foliage production of coriander (Anon., 2000). Thamburaj and Singh (2004) reported that staggered sowing and harvesting makes the fresh green leaf available for longer periods. The crop should be sown every two or three weeks to have lush coriander leaves throughout the growing season (Anon., 2011). Pruthi (2001) reported that the crop can be grown on raised beds under irrigated conditions throughout the year. So, it might be possible to produce green coriander i.e., fresh leaves throughout the year by dense planting in raised beds. Information for year round production of foliage of coriander in the country is scanty. Therefore, the present study was undertaken with the following objectives:

1. To observe the feasibility of growing coriander in different sowing dates for year round foliage production;

2. To determine the suitable genotype (s) capable of producing green leaves throughout the year.

\section{Materials and Method}

The experiment was conducted at the research farm of the Department of Horticulture, Bangabandhu Sheikh Mujibur Rahman Agricultural University, Gazipur during March 2008 to February 2009. The lines CS001, CS002, CS003, and CS008 were used in the present experiment in which CS001, CS002, CS003 were collected from Siddique Bazzar, Dhaka; while CS008 was collected from Tangail. These materials showed better performances in respect of foliage production in an earlier experiment. The experiment was laid out in split-plot design with three replications. Different sowing dates viz. 01 March $2008\left(D_{1}\right)$, 15 March $2008\left(D_{2}\right), 01$ April $2008\left(D_{3}\right), 15$ April $2008\left(D_{4}\right), 01$ May $2008\left(D_{5}\right)$, 15 May $2008\left(D_{6}\right), 01$ June $2008\left(D_{7}\right), 15$ June $2008\left(D_{8}\right), 01$ July $2008\left(D_{9}\right), 15$ July $2008\left(D_{10}\right), 01$ August $2008\left(D_{11}\right), 15$ August $2008\left(D_{12}\right), 01$ September $2008\left(D_{13}\right)$, 15 September $2008\left(D_{14}\right)$, 01 October $2008\left(D_{15}\right), 15$ October 2008 $\left(D_{16}\right), 01$ November $2008\left(D_{17}\right), 15$ November $2008\left(D_{18}\right)$, 01 December 2008 $\left(D_{19}\right), 15$ December $2008\left(D_{20}\right), 01$ January $2009\left(D_{21}\right), 15$ January $2009\left(D_{22}\right), 01$ February $2009\left(D_{23}\right)$, and 15 February $2009\left(D_{24}\right)$ were assigned in main plot and four genotypes viz., CS001, CS002, CS003 and CS004 were assigned in sub plot. The unit plot size was $3 \times 1 \mathrm{~m}$. Fertilizers were applied @ 5 tons cowdung, $90 \mathrm{~kg}$ urea, $50 \mathrm{~kg}$ TSP and $50 \mathrm{~kg}$ MoP per hectare (Moniruzzaman, 2011). The entire amount of cowdung, phosphorus from TSP and potassium from MoP with one-half of nitrogen from urea was applied during final land preparation. The rest of the nitrogen was applied at 20 days after sowing of seeds as top dress. The 
seeds (fruits) were rubbed for separating the mericarps (seeds) and were soaked in water for 24 hours to enhance germination. Seed were also treated with Bavistin @ 2 g per kg of seeds before sowing. The seeds of each genotype were sown in rows $10 \mathrm{~cm}$ apart continuously by hand @ $50 \mathrm{~kg} / \mathrm{ha}$ according to the sowing dates. First weeding was done at 20 days after sowing (DAS). Plant thinning was not done. For good germination, water was given to the plots every three days by water can with fine mashed nozzle till germination. From March to May irrigation was done at 7 days interval after emergence. Then irrigation was done at 10 days interval after emergence according to the need of the field soil.

Harvesting of plants was done by cutting just beneath the soil when few plants were seen to bolt depending upon the genotypes.

Table 1. Fifteen day interval air temperature and rainfall of each month during experimentation.

\begin{tabular}{|c|c|c|c|c|}
\hline \multirow[t]{2}{*}{ Date } & \multicolumn{3}{|c|}{ Air temperature $\left({ }^{\circ} \mathrm{C}\right)$} & \multirow{2}{*}{$\begin{array}{l}\text { Total Rainfall } \\
\text { (mm) }\end{array}$} \\
\hline & Max. & Min. & Ave. & \\
\hline 1-15 March/08 & 24.13 & 21.40 & 22.76 & 21.80 \\
\hline 16-31 March/08 & 28.13 & 25.46 & 26.79 & 0.70 \\
\hline 1-15 April/08 & 29.73 & 28.83 & 29.28 & 10.40 \\
\hline 16-30April/08 & 31.10 & 28.86 & 29.73 & 0.00 \\
\hline 1-15 May/08 & 30.86 & 29.73 & 30.29 & 119.40 \\
\hline 16-31May/08 & 31.66 & 28.60 & 30.13 & 106.80 \\
\hline 1 - 15 June/08 & 30.66 & 29.40 & 30.03 & 172.30 \\
\hline 16-30 June/08 & 30.59 & 28.13 & 29.36 & 148.82 \\
\hline 1-15 July/08 & 29.73 & 27.06 & 28.40 & 206.80 \\
\hline 16-31 July/08 & 30.73 & 28.03 & 29.38 & 35.70 \\
\hline 1-15 Aug./08 & 30.66 & 27.73 & 29.19 & 22.50 \\
\hline 16-31 Aug./08 & 30.90 & 27.40 & 28.90 & 15.40 \\
\hline 1-15 Sep./09 & 30.80 & 27.86 & 29.33 & 0.00 \\
\hline 16-30 Sep./08 & 30.46 & 27.53 & 29.00 & 55.80 \\
\hline 1-15 Oct./08 & 30.46 & 27.46 & 28.96 & 81.10 \\
\hline 16-31Oct./08 & 29.86 & 27.13 & 28.49 & 49.50 \\
\hline 1-15 Nov./08 & 27.87 & 22.20 & 25.03 & 0.00 \\
\hline 16-30 Nov./08 & 25.47 & 19.43 & 22.45 & 0.00 \\
\hline 1-15 Dec./08 & 25.00 & 17.46 & 21.23 & 0.00 \\
\hline 16-31 Dec./08 & 21.86 & 18.19 & 20.02 & 0.00 \\
\hline 1-15 Jan./09 & 20.43 & 15.20 & 17.82 & 0.00 \\
\hline 16 - 31 Jan./09 & 23.80 & 17.53 & 20.66 & 25.00 \\
\hline 1-15 Feb./09 & 23.10 & 17.20 & 20.17 & 0.00 \\
\hline 16-28 Feb./09 & 25.54 & 20.86 & 23.20 & 64.29 \\
\hline
\end{tabular}

Source: Weather Station, Dept. of Agricultural Engineering, BSMRAU, Salna, Gazipur. 
Data were collected from the inner rows of each plot to avoid the border effect. In each unit plot 10 plants were selected randomly for recording data on plant height $(\mathrm{cm})$, number of leaves/plant, plant weight (g) for foliage yield, number of plants $/ \mathrm{m}^{2}$, and plant weight $/ \mathrm{m}^{2}$. Plot yield was converted to per hectare yield. Weather data (air temperature and rainfall) were collected from the Weather Station, Dept. of Agricultural Engineering, BSMRAU, Salna, Gazipur (Table 1).

The collected data were properly analyzed statistically by MSTAT program and mean comparison was done following the Duncan's Multiple Range Test (DMRT).

\section{Results and Discussion}

\section{Effects of dates of sowing}

Seven sowings such as 15 April $2008\left(D_{4}\right), 01$ May $2008\left(D_{5}\right), 15$ May $2008\left(D_{6}\right)$, 01 June $2008\left(D_{7}\right), 15$ June $2008\left(D_{8}\right), 01$ July $2008\left(D_{9}\right), 15$ July $2008\left(D_{10}\right), 01$ August $2008\left(D_{11}\right)$ sowings were failed due to very poor germination and no foliage yield was obtained. The tallest plants were harvested from 15 November sowing $\left(D_{18}\right)(15.11 \mathrm{~cm})$, which was at par with 01 November $\left(D_{17}\right)$, 01 December $\left(D_{19}\right), 15$ December $\left(D_{20}\right), 01$ January $\left(D_{21}\right)$, and 1 February $\left(D_{23}\right)$ sowing (Table 2). The shortest plants were observed in $D_{3}$ (April 01) sowing $(6.51 \mathrm{~cm})$ closely followed by $\mathrm{D}_{12}$ (15 August), $\mathrm{D}_{13}$ (01 September), $\mathrm{D}_{14}$ (15 September) and $\mathrm{D}_{15}(01$ October) sowings. The maximum leaves were obtained from the plants of $\mathrm{D}_{17}$ sowing (6.09/plant) followed by $\mathrm{D}_{18}$ sowing (5.92/plant). The moderate leaves per plant were found in $\mathrm{D}_{20}, \mathrm{D}_{22}$ (January 15) and $\mathrm{D}_{23}$ sowing. The lowest leaves per plant was noticed in $\mathrm{D}_{13}$ sowing (4.71/plant) closely followed by that of $\mathrm{D}_{3}$ sowing. The $\mathrm{D}_{21}$ sowing gave the maximum plant weight (1.44g/plant) closely followed by $\mathrm{D}_{19}$ sowing ( $1.43 \mathrm{~g} /$ plant). The moderate plant weight was observed in $\mathrm{D}_{17}$ and $\mathrm{D} 18$ sowings. The plant weight was found minimum in $\mathrm{D}_{3}$ sowing (0.74 g/plant). The maximum plants $/ \mathrm{m}^{2}$ were obtained from $\mathrm{D}_{24}$ sowing (551) followed by $\mathrm{D}_{23}$ sowing (529). The moderate plants per square meter were observed in $D_{20}, D_{21}$ and $D_{22}$ sowings. The lowest plants were noticed in $D_{3}$ sowing $\left(231 / \mathrm{m}^{2}\right)$ which was identical with $\mathrm{D}_{12}$ sowing.

A negative linear relationship between temperature and plants per square meter was found to be highly significant $\left(r=-0.85^{* *}\right)$ (Fig. 1). The negative relationship indicated that number of plants $/ \mathrm{m}^{2}$ decreased with the increase in air temperature. The linear equation $\left(y=-20.294 x+912.19, \mathrm{R}^{2}=0.7346\right)$ stated that for every increase of $1^{\circ} \mathrm{C}$ temperature about 20 plants were decreased per square meter. The value of coefficient of determination $\left(\mathrm{R}^{2}\right)$ indicated that $73.46 \%$ decrease of plants $/ \mathrm{m}^{2}$ was due to high temperature. 


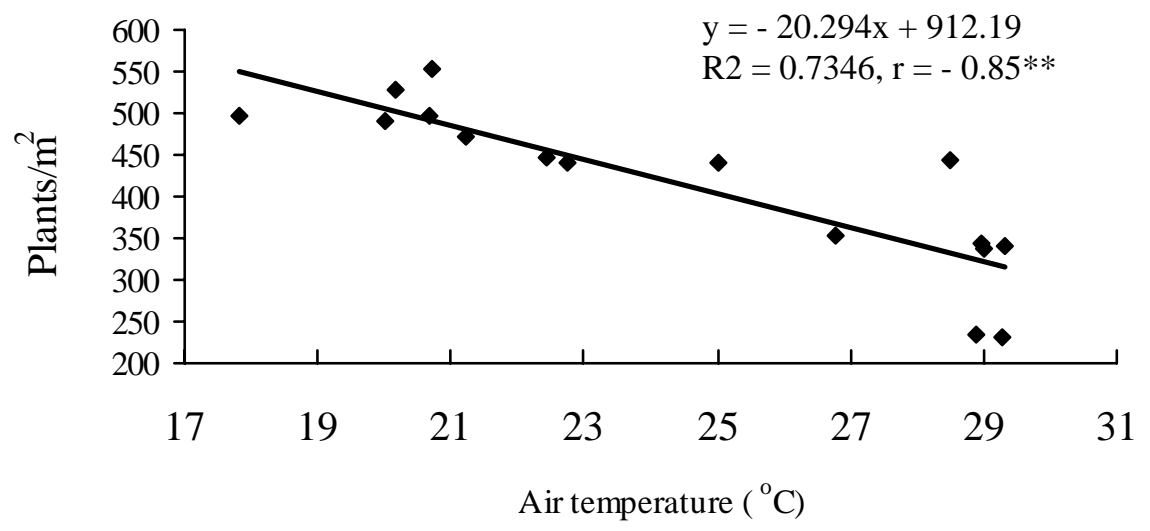

Figure 1. Relationship between air temperature and number of coriander plants $/ \mathrm{m}^{2}$

Table 2. Yield attributes of foliage coriander as influenced by different dates of sowing.

\begin{tabular}{|c|c|c|c|c|c|c|}
\hline Treatment & $\begin{array}{l}\text { Plant height } \\
\text { (cm) }\end{array}$ & $\begin{array}{c}\text { Leaves/plant } \\
\text { (no.) }\end{array}$ & \begin{tabular}{|c|} 
Individual \\
plant weight \\
(g)
\end{tabular} & $\begin{array}{c}\text { Plants/m² } \\
\text { (no.) }\end{array}$ & $\begin{array}{c}\text { Plant } \\
\text { weight } / \mathrm{m}^{2} \\
(\mathrm{~kg})\end{array}$ & $\begin{array}{c}\text { Foliage } \\
\text { yield } \\
\text { (t/ha) }\end{array}$ \\
\hline $\mathrm{D}_{1}$ & $9.14 \mathrm{e}$ & $5.00 \mathrm{f}$ & $0.88 f g$ & $441 \mathrm{e}$ & $348.7 \mathrm{~g}$ & $3.41 \mathrm{~g}$ \\
\hline $\mathrm{D}_{2}$ & $8.27 f$ & 4.93fg & $0.85 \mathrm{gh}$ & $353 f$ & 293.5h & $2.84 \mathrm{~h}$ \\
\hline $\mathrm{D}_{3}$ & $6.51 \mathrm{~h}$ & 4.82gh & $0.74 \mathrm{k}$ & 231h & $162.3 \mathrm{j}$ & $1.61 \mathrm{j}$ \\
\hline $\mathrm{D}_{12}$ & 6.83gh & 4.75h & $0.78 \mathrm{j}$ & $233 \mathrm{~h}$ & $175.0 \mathrm{j}$ & $1.74 \mathrm{j}$ \\
\hline $\mathrm{D}_{13}$ & 6.86gh & 4.71h & 0.79ij & $340 \mathrm{~g}$ & 265.3i & $2.60 \mathrm{i}$ \\
\hline $\mathrm{D}_{14}$ & 7.07gh & $5.06 \mathrm{f}$ & 0.82hi & 335g & 271.5i & 2.71hi \\
\hline $\mathrm{D}_{15}$ & 7.33g & 5.31de & $0.87 \mathrm{~g}$ & $345 f g$ & 294.9h & $2.89 \mathrm{~h}$ \\
\hline $\mathrm{D}_{16}$ & $11.32 d$ & $5.25 \mathrm{e}$ & $1.03 \mathrm{e}$ & 443e & $451.7 f$ & $4.42 \mathrm{f}$ \\
\hline $\mathrm{D}_{17}$ & $15.10 \mathrm{a}$ & $6.09 a$ & $1.37 \mathrm{bc}$ & $442 \mathrm{e}$ & 547.7e & $5.36 \mathrm{e}$ \\
\hline $\mathrm{D}_{18}$ & $15.11 \mathrm{a}$ & $5.92 b$ & $1.39 b$ & $446 e$ & 562.3e & $5.34 \mathrm{e}$ \\
\hline $\mathrm{D}_{19}$ & $14.85 a$ & $5.45 d$ & $1.43 a$ & $471 d$ & $617.6 b$ & $6.05 b$ \\
\hline $\mathrm{D}_{20}$ & $14.66 a$ & $5.67 c$ & $1.34 \mathrm{c}$ & 491c & 594.4c & $5.82 \mathrm{c}$ \\
\hline $\mathrm{D}_{21}$ & $13.03 c$ & $5.45 d$ & $1.44 \mathrm{a}$ & 497c & $650.8 a$ & 6.38a \\
\hline$D_{22}$ & $13.95 b$ & $5.67 c$ & $1.25 \mathrm{~d}$ & 497c & 564.9de & 5.54de \\
\hline$D_{23}$ & 14.53ab & $5.71 \mathrm{c}$ & $1.23 \mathrm{~d}$ & $529 b$ & 585.1cd & 5.73cd \\
\hline $\mathrm{D}_{24}$ & 9.69e & $4.92 \mathrm{fg}$ & $0.92 \mathrm{f}$ & 551a & $459.6 \mathrm{f}$ & $4.50 \mathrm{f}$ \\
\hline Mean & 10.89 & 5.29 & 1.07 & 415.41 & 427.83 & 4.18 \\
\hline CV (\%) & 6.17 & 5.45 & 3.14 & 4.40 & 4.77 & 4.65 \\
\hline LSD $(0.0$ & 0.631 & 0.149 & 0.372 & 10.74 & 20.44 & 0.209 \\
\hline
\end{tabular}

Means showing same letters in a column are not significantly different at $5 \%$ level by DMRT. 
April 15, $2008\left(D_{4}\right)$, May 01, $2008\left(D_{5}\right)$, May 15, $2008\left(D_{6}\right)$, June 01, 2008( $\left.D_{7}\right)$, June 15 , 2008( $\left(D_{8}\right)$, July $01,2008\left(D_{9}\right)$, July $15,2008\left(D_{10}\right)$,, August $01,2008\left(D_{11}\right)$, sowings were failed.

The $D_{21}$ sowing gave the highest weight of plants $/ \mathrm{m}^{2}$ (650.8g) followed by $\mathrm{D}_{19}$ sowing $(617.6 \mathrm{~g})$. The moderate weight of plants $/ \mathrm{m}^{2}$ was observed in $\mathrm{D}_{17}$, $D_{18}, D_{20}, D_{22}$, and $D_{23}$ sowings. There was a negative linear relationship between temperature and foliage yield per square meter (Fig. 2). The negative relationship indicated that foliage yield/ha decreased with the increasing of air temperature. The equation $\left(\mathrm{y}=-0.3446 \mathrm{x}+12.651, \mathrm{R}^{2}=0.7641, \mathrm{r}=-0.87^{* *}\right)$ stated that for every increase of $1^{\circ} \mathrm{C}$ temperature about $345 \mathrm{~g}$ foliage was decreased per hectare. The $\mathrm{R}^{2}$ value indicated that $76.41 \%$ decrease of foliage was due to high temperature.

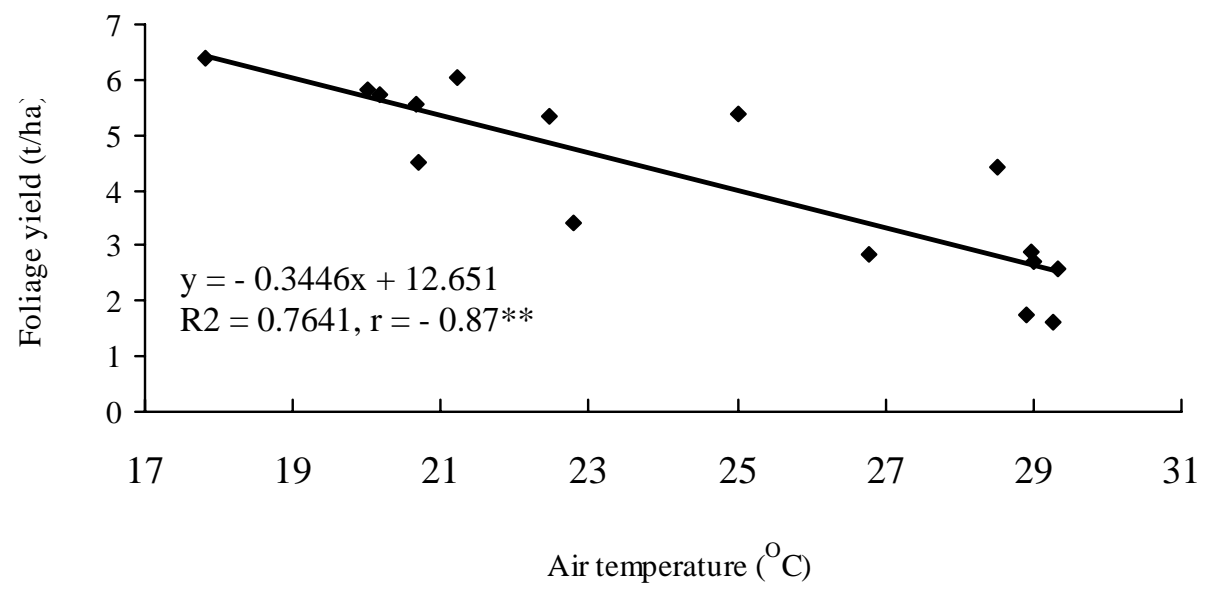

Fig. 2. Relationship between air temperature and foliage yield in coriander at different sowing dates.

The highest foliage yield was obtained from $\mathrm{D}_{21}$ sowing (6.38 $\mathrm{t} / \mathrm{ha}$ ) followed by that of D19 sowing (6.05 t/ha) (Table 2.) The moderate foliage yield was observed in $\mathrm{D}_{20}(5.82 \mathrm{t} / \mathrm{ha}), \mathrm{D}_{22}(5.54 \mathrm{t} / \mathrm{ha})$, and $\mathrm{D}_{23}(5.73 \mathrm{t} / \mathrm{ha})$ sowings. The yield range of 4.43 to $5.34 \mathrm{t} / \mathrm{ha}$ was from $\mathrm{D}_{16}$ to $\mathrm{D}_{18}$ sowings. No significant difference was observed between $D_{20}$ and $D_{24}$ sowings in respect of foliage yield per hectare.

The average air temperature was $25.03^{\circ} \mathrm{C}$ to $17.82^{\circ} \mathrm{C}$ from 01 November to 28 February (Table 1). Due to this favorable temperature, the foliage yield attributes viz., plant height, leaves/plant and plant weight, plants $/ \mathrm{m}^{2}$ were good enough to produce reasonable foliage yield per hectare. Irrigation was required frequently (7 days interval) for survival and growth of the plants from 15 August to 31 October due to high temperature in this period. Besides, moisture was kept available during germination period for satisfactory plant stand, yet seedlings were not up to the 
mark during this period. Plant weight was lower during this period (15 August to October 15 sowing) because the plants were harvested before 30 days of sowing. Plants were harvested within a short time because of bolting due to high temperature. For this reason, seeds were sown every 15 days interval for harvesting foliage regularly during hot weather though the plants were tiny.

\section{Performance of genotypes}

The genotype CS003 had the maximum plant height $(12.91 \mathrm{~cm})$ followed by CS002 $(11.60 \mathrm{~cm})$ and CS001 $(11.15 \mathrm{~cm})$ (Table 3). The lowest plant height was obtained from the genotype CS008 $(7.92 \mathrm{~cm})$. The maximum number of leaves was also found in CS003 (5.67/plant), which was followed by CS001 (5.55/plant) and CS002 (5.48/plant). The genotype CS008 gave the lowest number of leaves (4.47/plant).

Table 3. Yield attributes of foliage coriander as influenced by genotypes.

\begin{tabular}{l|c|c|c|c|c|c}
\hline Treatment & $\begin{array}{c}\text { Plant } \\
\text { height } \\
\text { (cm) }\end{array}$ & $\begin{array}{c}\text { Leaves/plant } \\
\text { (no.) }\end{array}$ & $\begin{array}{c}\text { Individual } \\
\text { plant weight } \\
\text { (g) }\end{array}$ & $\begin{array}{c}\text { Plants/m } \\
\text { (no.) }\end{array}$ & $\begin{array}{c}\text { Plant } \\
\mathrm{wt} / \mathrm{m}^{2}(\mathrm{~g})\end{array}$ & $\begin{array}{c}\text { Foliage } \\
\text { yield } \\
\text { (t/ha) }\end{array}$ \\
\hline CS001 & $11.15 \mathrm{c}$ & $5.55 \mathrm{~b}$ & $1.15 \mathrm{~b}$ & $418 \mathrm{~b}$ & $455.3 \mathrm{c}$ & $4.48 \mathrm{~b}$ \\
CS002 & $11.60 \mathrm{~b}$ & $5.48 \mathrm{~b}$ & $1.21 \mathrm{ab}$ & $404 \mathrm{c}$ & $465.2 \mathrm{~b}$ & $4.54 \mathrm{~b}$ \\
CS003 & $12.91 \mathrm{a}$ & $5.67 \mathrm{a}$ & $1.27 \mathrm{a}$ & $433 \mathrm{a}$ & $523.8 \mathrm{a}$ & $5.12 \mathrm{a}$ \\
CS008 & $7.92 \mathrm{~d}$ & $4.47 \mathrm{c}$ & $0.67 \mathrm{c}$ & $407 \mathrm{c}$ & $267.0 \mathrm{~d}$ & $2.6 \mathrm{c}$ \\
\hline Mean & 10.89 & 5.29 & 1.07 & 416 & 427.83 & 4.18 \\
CV (\%) & 6.17 & 5.45 & 3.14 & 4.40 & 4.77 & 4.65 \\
LSD (0.05) & 0.298 & 0.116 & 0.069 & 4.05 & 8.27 & 0.078 \\
\hline
\end{tabular}

Means showing same letters in a column are not significant at $5 \%$ level by DMRT.

The maximum plant weight was obtained from CS003 (1.27 g) closely followed by that of CS002 (1.21 g) and the minimum from CS008 (0.67 g). The genotype CS003 produced the highest plants $/ \mathrm{m}^{2}$ (433) followed by CS001 (418). The lowest plants $/ \mathrm{m}^{2}$ was observed in CS008 (407). The maximum foliage yield was obtained from the genotype CS003 (5.12 t/ha) followed by CS002 (4.54 t/ha) and CS001 (4.48 t/ha) (Table 3). There was no significant difference between CS001 and CS002 in respect of foliage yield per hectare. The lowest foliage yield was produced by CS008 (2.60 t/ha). The genotype CS003 was late to bolting and thus gave the highest foliage yield. CS008 gave the lowest foliage yield as it was early to bolting. CS001 and CS002 were very early to bolting and gave moderate foliage yield.

\section{Combined effect of sowing date and genotype}

The combination of $\mathrm{D}_{19} \times \mathrm{CS} 003$ produced the tallest plant $(17.37 \mathrm{~cm})$, which was identical with $\mathrm{D}_{17} \times \mathrm{CS} 003, \mathrm{D}_{18} \times \mathrm{CS} 003, \mathrm{D}_{20} \times \mathrm{CS} 003, \mathrm{D}_{22} \times \mathrm{CS} 003, \mathrm{D}_{17} \times$ 
CS002, $\mathrm{D}_{18} \times$ CS002 and the genotype CS008 produced the shortest plant when interacted with $D_{1}$ to $D_{15}$ sowings. In every sowing, except $D_{1}$, CS003 gave the tallest plant compared to other genotypes and CS008 performed the poorest in each sowing in respect of plant height. Except $D_{1}, D_{21}, D_{23}$, and $D_{24}$ sowings, CS002 showed better results than CS001. In $D_{1}, D_{21}, D_{23}$ and $D_{24}$ sowings CS002 and CS002 exhibited the similar results in respect of plant height.

The combination of $\mathrm{D}_{24} \times \mathrm{CS} 001$ gave the highest number of plants $/ \mathrm{m}^{2}$ (583) closely followed by $\mathrm{D}_{23} \times \mathrm{CS} 001$ (571). The lowest plants $/ \mathrm{m}^{2}$ was observed in $\mathrm{D}_{3}$ sowing when interacted with each genotype. In $D_{2}, D_{3}, D_{12}, D_{13}, D_{14}, D_{15}, D_{23}$, and $\mathrm{D}_{24}$ sowings, CS001 produced maximum number of plants $/ \mathrm{m}^{2}$ compared to other genotypes and in $\mathrm{D}_{16}, \mathrm{D}_{17}, \mathrm{D}_{19}, \mathrm{D}_{20}, \mathrm{D}_{21}$, and $\mathrm{D}_{22}$ sowings CS003 produced maximum number of plants $/ \mathrm{m}^{2}$ compared to other genotypes.

Table 4. Plant weight $/ \mathrm{m}^{2}$ of coriander as influenced by interaction of sowing dates and genotypes.

\begin{tabular}{c|c|c|c|c|c}
\hline $\begin{array}{c}\text { Sowing } \\
\text { date (D) }\end{array}$ & CS001 & CS002 & CS003 & CS008 & Mean \\
\hline $\mathrm{D}_{1}$ & $412.0 \mathrm{no}$ & $383.0 \mathrm{opq}$ & $422.6 \mathrm{n}$ & $177.3 \mathrm{y}$ & 348.7 \\
$\mathrm{D}_{2}$ & $359.9 \mathrm{p}-\mathrm{s}$ & $329.4 \mathrm{rst}$ & $367.2 \mathrm{pqr}$ & $117.6 \mathrm{z}$ & 293.3 \\
$\mathrm{D}_{3}$ & $187.0 \mathrm{y}$ & $177.6 \mathrm{y}$ & $226.5 \mathrm{wx}$ & $58.20 \backslash$ & 162.3 \\
$\mathrm{D}_{12}$ & $204.6 \mathrm{wxy}$ & $192.0 \mathrm{xy}$ & $233.7 \mathrm{w}$ & 69.67 & 175.0 \\
$\mathrm{D}_{13}$ & $322.5 \mathrm{stu}$ & $288.5 \mathrm{uv}$ & $349.3 \mathrm{qrs}$ & $100.9 \mathrm{z} \mathrm{[}$ & 265.3 \\
$\mathrm{D}_{14}$ & $330.5 \mathrm{rst}$ & $303.1 \mathrm{tuv}$ & $347.9 \mathrm{qrs}$ & $104.7 \mathrm{z}$ & 271.5 \\
$\mathrm{D}_{15}$ & $353.0 \mathrm{qrs}$ & $329.6 \mathrm{rst}$ & $373.4 \mathrm{pq}$ & $123.7 \mathrm{z}$ & 294.9 \\
$\mathrm{D}_{16}$ & $504.2 \mathrm{~lm}$ & $475.4 \mathrm{l}$ & $499.1 \mathrm{~lm}$ & $328.2 \mathrm{st}$ & 451.7 \\
$\mathrm{D}_{17}$ & $615.1 \mathrm{gh}$ & $589.5 \mathrm{hi}$ & $605.1 \mathrm{gh}$ & $381.0 \mathrm{opq}$ & 547.7 \\
$\mathrm{D}_{18}$ & $592.0 \mathrm{hi}$ & $585.2 \mathrm{hij}$ & $653.6 \mathrm{ef}$ & $418.3 \mathrm{no}$ & 562.3 \\
$\mathrm{D}_{19}$ & $521.8 \mathrm{kl}$ & $691.3 \mathrm{~cd}$ & $872.5 \mathrm{a}$ & $385.1 \mathrm{opq}$ & 617.6 \\
$\mathrm{D}_{20}$ & $566.0 \mathrm{ij}$ & $704.2 \mathrm{c}$ & $715.3 \mathrm{c}$ & $392.0 \mathrm{nop}$ & 594.4 \\
$\mathrm{D}_{21}$ & $606.6 \mathrm{gh}$ & $695.5 \mathrm{c}$ & $806.8 \mathrm{~b}$ & $494.5 \mathrm{~lm}$ & 650.8 \\
$\mathrm{D}_{22}$ & $498.5 \mathrm{~lm}$ & $586.9 \mathrm{hij}$ & $704.1 \mathrm{c}$ & $469.9 \mathrm{~m}$ & 564.9 \\
$\mathrm{D}_{23}$ & $659.5 \mathrm{def}$ & $632.4 \mathrm{fg}$ & $678.6 \mathrm{cde}$ & $369.9 \mathrm{pq}$ & 585.1 \\
$\mathrm{D}_{24}$ & $551.0 \mathrm{jk}$ & $480.2 \mathrm{~m}$ & $528.8 \mathrm{kl}$ & $281.3 \mathrm{v}$ & 459.6 \\
\hline $\mathrm{Mean}$ & 455.3 & 465.2 & 523.8 & 267.0 & 427.83 \\
$\mathrm{CV}_{(\%)}$ & & 4.77 & & & \\
\hline
\end{tabular}

Means showing same letters or symbols are not significant at 5\% level by DMRT.

Among all the combinations, the maximum plant weight $/ \mathrm{m}^{2}$ was obtained from $\mathrm{D}_{19} \times \mathrm{CS} 003$ combination $\left(872.5 \mathrm{~g} / \mathrm{m}^{2}\right)$ followed by that of $\mathrm{D}_{21} \times \mathrm{CS} 003$, $\mathrm{D}_{20} \times \mathrm{CS} 003, \mathrm{D}_{22} \times \mathrm{CS} 003, \mathrm{D}_{23} \times \mathrm{CS} 003, \mathrm{D}_{19} \times \mathrm{CS} 002, \mathrm{D}_{20} \times \mathrm{CS} 002$ and $\mathrm{D}_{21} \times$ 
CS002 and the minimum plant weight $/ \mathrm{m}^{2}$ was observed in $\mathrm{D}_{3} \times \mathrm{CS} 008$ combination (Table 4). The $\mathrm{D}_{3}$ sowing showed the poorest results irrespective of genotypes with regard to plant weight $/ \mathrm{m}^{2}$. The reasonable plant weight $/ \mathrm{m}^{2}$ was obtained from CS001 $\left(322.5-659.5 \mathrm{~g} / \mathrm{m}^{2}\right)$ in all sowings except $\mathrm{D}_{3}$ and $\mathrm{D}_{12}$, being the maximum plant weight $/ \mathrm{m}^{2}$ from $\mathrm{D}_{23} \times \mathrm{CS} 001$ combination $\left(659.5 \mathrm{~g} / \mathrm{m}^{2}\right)$ followed by that of $\mathrm{D}_{21} \times \mathrm{CS} 001, \mathrm{D}_{17} \times \mathrm{CS} 001$ and the minimum was observed in $\mathrm{D}_{3} \times$ CS001 combination. The genotype CS002 gave handsome plant weight $/ \mathrm{m}^{2}$ of $303.1-704.2 \mathrm{~g} / \mathrm{m}^{2}$ in each sowing except $\mathrm{D}_{3}, \mathrm{D}_{12}$ and $\mathrm{D}_{13}$; the combination of $\mathrm{D}_{20} \times \mathrm{CS} 002$ gave the highest plant weight $\left(704.2 \mathrm{~g} / \mathrm{m}^{2}\right)$, which was statistically at par with $\mathrm{D}_{19} \times \mathrm{CS} 002$ and $\mathrm{D}_{21} \times \mathrm{CS} 002$. The combination $\mathrm{D}_{21}$ x CS008 produced maximum weight of plants $/ \mathrm{m}^{2}$ (494.5 g) which was at par with $\mathrm{D}_{22} \times \mathrm{CS} 008$ and minimum weight of plants $/ \mathrm{m}^{2}$ was produced when CS008 interacted with $\mathrm{D}_{3}$ sowings. In all sowings CS008 gave the lowest plant weight $/ \mathrm{m}^{2}$ compared to other genotypes.

Table 5. Foliage yield/ha of coriander as influenced by interaction of sowing dates and different Genotypes.

\begin{tabular}{ccc|c|c|c}
\hline $\begin{array}{c}\text { Sowing } \\
\text { date(D) }\end{array}$ & CS001 & CS002 & CS003 & CS008 & Mean \\
\hline $\mathrm{D}_{1}$ & $4.14 \mathrm{n}$ & $3.73 \mathrm{pqr}$ & $4.11 \mathrm{no}$ & 1.65[ & 3.41 \\
$\mathrm{D}_{2}$ & $3.47 \mathrm{q}-\mathrm{u}$ & $3.20 \mathrm{tuv}$ & $3.56 \mathrm{p}-\mathrm{t}$ & $1.15 \backslash$ & 2.84 \\
$\mathrm{D}_{3}$ & $1.85 \mathrm{z} \mathrm{[}$ & $1.76 \mathrm{z} \mathrm{[}$ & $2.24 \mathrm{xy}$ & $0.58]$ & 1.61 \\
$\mathrm{D}_{12}$ & $2.02 \mathrm{xyz}$ & $1.90 \mathrm{yz}[$ & $2.33 \mathrm{x}$ & $0.69]$ & 1.74 \\
$\mathrm{D}_{13}$ & $3.18 \mathrm{uv}$ & $2.81 \mathrm{w}$ & $3.39 \mathrm{r}-\mathrm{u}$ & $1.01 \backslash$ & 2.60 \\
$\mathrm{D}_{14}$ & $3.30 \mathrm{~s}-\mathrm{v}$ & $3.02 \mathrm{v}-\mathrm{w}$ & $3.46 \mathrm{q}-\mathrm{u}$ & $1.04 \backslash$ & 2.71 \\
$\mathrm{D}_{15}$ & $3.45 \mathrm{q}-\mathrm{u}$ & $3.23 \mathrm{tuv}$ & $3.65 \mathrm{p}-\mathrm{s}$ & $1.21 \backslash$ & 2.89 \\
$\mathrm{D}_{16}$ & $4.94 \mathrm{~lm}$ & $4.66 \mathrm{~m}$ & $4.89 \mathrm{~lm}$ & $3.22 \mathrm{tuv}$ & 4.42 \\
$\mathrm{D}_{17}$ & $6.03 \mathrm{gh}$ & $5.77 \mathrm{hi}$ & $5.93 \mathrm{gh}$ & $3.73 \mathrm{pqr}$ & 5.36 \\
$\mathrm{D}_{18}$ & $5.96 \mathrm{gh}$ & $5.37 \mathrm{jkc}$ & $6.22 \mathrm{fg}$ & $3.81 \mathrm{n}-\mathrm{q}$ & 5.34 \\
$\mathrm{D}_{19}$ & $5.11 \mathrm{kl}$ & $6.77 \mathrm{cde}$ & $8.55 \mathrm{a}$ & $3.77 \mathrm{opq}$ & 6.05 \\
$\mathrm{D}_{20}$ & $5.55 \mathrm{ij}$ & $6.90 \mathrm{~cd}$ & $7.01 \mathrm{c}$ & $3.84 \mathrm{nop}$ & 5.82 \\
$\mathrm{D}_{21}$ & $5.95 \mathrm{gh}$ & $6.82 \mathrm{~cd}$ & $7.90 \mathrm{~b}$ & $4.85 \mathrm{~lm}$ & 6.38 \\
$\mathrm{D}_{22}$ & $4.88 \mathrm{~lm}$ & $5.75 \mathrm{hi}$ & $6.90 \mathrm{~cd}$ & $4.63 \mathrm{~m}$ & 5.54 \\
$\mathrm{D}_{23}$ & $6.46 \mathrm{ef}$ & $6.20 \mathrm{fg}$ & $6.65 \mathrm{de}$ & $3.62 \mathrm{ps}$ & 5.73 \\
$\mathrm{D}_{24}$ & $5.40 \mathrm{gk}$ & $4.70 \mathrm{~m}$ & $5.15 \mathrm{kl}$ & $2.76 \mathrm{w}$ & 4.50 \\
\hline Mean & 4.48 & 4.54 & 5.12 & 2.60 & 4.18 \\
$\mathrm{CV}(\%)$ & & 4.65 & & & \\
\hline
\end{tabular}

Means showing same letters or symbols are not significant at 5\% level by DMRT.

Foliage yield ranged from 0.58 to $8.55 \mathrm{t} / \mathrm{ha}$ (Table 5). The maximum foliage yield was recorded from $\mathrm{D}_{19} \times \mathrm{CS003}$ combination ( $8.55 \mathrm{t} / \mathrm{ha}$ ) followed by that of 
$\mathrm{D}_{21} \times \mathrm{CS} 003, \mathrm{D}_{20} \times \operatorname{CS} 003(7.90 \mathrm{t} / \mathrm{ha})$ and the minimum foliage yield was observed in $\mathrm{D}_{3} \times \mathrm{CS} 008$ and $\mathrm{D}_{12} \times \mathrm{CS} 008$ combinations. The $\mathrm{D}_{3}$ sowing gave the poorest results irrespective of genotypes with regard to foliage yield followed by $\mathrm{D}_{12}$ sowing. The genotype CS001 produced reasonable yields (4 to $6.46 \mathrm{t} / \mathrm{ha}$ ) when the plants of this genotype were sown in 01 March $\left(D_{1}\right), 15$ March $\left(D_{2}\right)$ and during 01 September $\left(D_{13}\right)$ to 15 February $\left(D_{24}\right)$. The $D_{23} \times$ CS001 combination $(6.46 \mathrm{t} / \mathrm{ha})$ gave maximum foliage yield, which was followed by $\mathrm{D}_{17} \times \mathrm{CS001}$, $\mathrm{D}_{18} \times \mathrm{CS} 001$, and $\mathrm{D}_{21} \times \mathrm{CS} 001$. The reasonable good yields were also recorded from the genotype CS002 (3.02 - 6.90 t/ha) from all the sowings except $\mathrm{D}_{3}, \mathrm{D}_{12}$, and $\mathrm{D}_{13}$ and from CS003 (3.39 - $7.90 \mathrm{t} / \mathrm{ha}$ ) from all sowings except $\mathrm{D}_{3}$ and $\mathrm{D}_{12}$. In case of CS002, the combination of $\mathrm{D}_{20} \times \mathrm{CS} 002$ produced the maximum foliage yield (6.90 t/ha), which was statistically at par with $\mathrm{D}_{19} \times \mathrm{CS} 002$ and $\mathrm{D}_{21}$ $\times$ CS002. In case of CS003, the moderate foliage yield (5.15-7.01 t/ha) were observed in $\mathrm{D}_{24} \times$ CS003, $\mathrm{D}_{17} \times \mathrm{CS} 003, \mathrm{D}_{18} \times \mathrm{CS} 003, \mathrm{D}_{22} \times \mathrm{CS} 003$ and $\mathrm{D}_{23} \times$ CS003 combinations. The genotype CS008 produced maximum foliage yield (494.5 g) when interacted with $D_{21}$ sowings being at par with $D_{22}$ sowing and minimum foliage yield was produced when CS008 interacted with $\mathrm{D}_{3}$ sowings. In all sowings CS008 gave the minimum foliage yield per hectare compared to other genotypes.

It had been observed that performances of the genotypes were the poorest during hot seasons of $D_{3}$ to $D_{13}$ sowings (01 April 2008 to 01 September 2008), besides 15 April $2008\left(D_{4}\right), 01$ May $2008\left(D_{5}\right), 15$ May $2008\left(D_{6}\right)$, 01 June 2008 $\left(D_{7}\right), 15$ June $2008\left(D_{8}\right), 01$ July $2008\left(D_{9}\right), 15$ July $2008\left(D_{10}\right), 01$ August 2008 $\left(D_{11}\right)$ sowings failed due to very poor germination resulted from relatively high temperature. Pruthi (2001) reported that for production of coriander leaves, the crop can be sown any time of the year excepting when temperature is too high (April to June). Thamburaj and Singh (2004) also opined that coriander is grown throughout the year for leaf purpose with the except of March-May months. It is also seen that except $\mathrm{D}_{3}, \mathrm{D}_{12}$, and $\mathrm{D}_{13}$, the genotypes CS001, CS002, and CS003 genotypes gave reasonable foliage yield in all sowings while CS008 produced the same except $\mathrm{D}_{1}$ to $\mathrm{D}_{15}$ sowings. It became possible because CS001, CS002, and CS003 were tolerant to high temperature except CS008.

The results led to conclude that the genotypes CS001, CS002, and CS003 should be sown from 01 September to 01 February, while the genotype CS008 should be sown from October 15 to February 01 for foliage yield of coriander.

\section{References}

Anonymous. 2000. Growing Coriander. http://www.ucanr.org/freepubs/docs/7236.pdf.

Anonymous. 2011. Cilantro Prloduction in California. Univ. California. Agric. Natural Sci. httpp:// www.gardeningpatch.com/herbs/growing-coriander-cilantro. aspx. 
Janardhonan, M. and J. E. Thoppil. 2004. Herb and Spice Essential Oils. Discovery Publishing House, New Delhi-110002. Pp. 40-42.

Moniruzzaman, M. 2011. Foliage and Seed Production Technology of Coriander. Ph.D. Dissertation. Dept. of Hort., Bangabandhu Sheikh Mujibur Rahman Agril. Univ. (BSMRAU), Salna, Gazipur-1706. P. 79.

Pruthi, J. S. 2001. Minor Spices and Condimends crop Management and post harvest Technology. Directorate of Information and Publication of Agriculture, Indian council of Agril. Res. Krishi Anusandhan Bhaban, Pusha, New Delhi. Pp. 162-185.

Sharma, M, M. and R. K. Sharma. 2004. Coriander. In: Handbook of herbs and spices. Vol. 2 (ed.) Peter K. V. Woodhead Pub. Ld., Abington Hall, Abington cambridge CBI 6AH, England. Pp. 145-161.

Thamburaj, S. and N. Singh. 2004. Vegetables, Tubercrops and Spices. Kuldeep Sharma, incharge Directorate of Information and Publication of Agriculture. Indian Council of Agril. Res. Krishi Anusandhan Bhaban, Pusha, New Delhi 110012. Pp. 371-374. 